\title{
YOUTHS AS AN AGENT FOR PEACEBUILDING: A CASE STUDY OF MAIDUGURI, BORNO STATE, NIGERIA
}

\author{
${ }^{* 1}$ Abubakar, A. \\ ${ }^{*}$ Centre for Peace, Diplomatic and Development Studies, University of Maiduguri, Nigeria \\ *Corresponding Author Email: abubakaramsami@ gmail.com Phone: +2348058310614
}

\begin{abstract}
Young people need to be recognized and supported to play a major role as agents of peace. The society needs to partner with them to form a sine qua non (an essential condition) in promoting the global agenda for youth involvement in sustainable peace. Peacebuilding is broadly defined as an 'action to identify and support structures which tends to strengthen and solidify peace in order to avoid a relapse into conflict.' Therefore, peacebuilding is directed towards the eradication of the root causes of violence and is necessarily a multifaceted and multidimensional project that involves political, legal, economic, social, religious and cultural institutions and security practices, which are understood as complementary and mutually reinforcing. This paper examines how the involvement of youths in the peacebuilding process can promote sustainable peace in Maiduguri, Borno State, as a result of the Boko Haram conflict to avoid future occurrences of such conflict. The objective of the study is to explore the role Maiduguri youths can play in building sustainable and long-term peace in Maiduguri, Borno State as a critical stakeholder. The study employs the multidimensional research method also as a peer-review paper, the secondary source of data was used. The finding reveals that youth are critical stakeholders in peacebuilding and should be involved at all stages of the peace process. The study recommends that the Borno State Government should formulate policies and programs that are directed towards youth's engagement in governance, address unemployment problem etc. since participatory democracy, youth empowerment, and social wellbeing are critical drivers of sustainable development, peace and security.
\end{abstract}

Keywords: Youths, peacebuilding, sustainable development, Bokoharam, empowerment

LICENSE: This work by Open Journals Nigeria is licensed and published under the Creative Commons Attribution License 4.0 International License, which permits unrestricted use, distribution, and reproduction in any medium, provided this article is duly cited.

COPYRIGHT: The Author(s) completely retain the copyright of this published article.

OPEN ACCESS: The Author(s) approves that this article remains permanently online in the open access (OA) model.

QA: This Article is published in line with "COPE (Committee on Publication Ethics) and PIE (Publication Integrity \& Ethics)". 


\section{INTRODUCTION}

Although there are more young people living on the planet today than ever before; it is quite inappropriate as history shows that the burden of violence and war rest on the shoulders of the younger generation in every society. It calls for a deep reflection seeing the role youths play in the nature of crisis observed all around the world, even with their greater number and population.

This huge population is a point of justification for the inclusion and consideration of youth in policymaking and planning of peacebuilding processes (Cursi, 2017). Young people need to be recognized and supported to play an important role as an agent of peace. And the society needs to partners with them to form a sine qua non in order to promote the global agenda for youth involvement in sustainable peace (UN, 2015). Also, Youth wellbeing, participation and empowerment are key drivers of sustainable development and peace around the world.

Peacebuilding is an initiative that promotes peace by addressing the roots of conflict, preventing and mitigating all forms of violence, and fostering just and inclusive societies. This vision of inclusion is predicated on the inclusion of all members of society, particularly youth, and strives to promote a culture of peace (George, 2019). Various international communities have undertaken several initiatives that involves youth for peacebuilding and promotion of international peace and security. Such activities are to advance and support youth interest in dynamic peacebuilding. Some of these activities include the World Conference for Youth, Sri Lanka, May 2014; the main Global Forum on Youth Policies, Azerbaijan 2014; the Hashemite Kingdom of Jordan on The Role of Young People in Countering Violent Extremism and Promoting Peace, 2015; Amman Youth Declaration on Youth, Peace and Security; US Department of State, co-facilitated Global Youth Summit Against Extremism in 2015.

All these fora are envisioned to collaborate with youths in forestalling violence, countering brutal radicalism and building an enduring peace. In Nigerian, the National Youth Council is also playing an important role in peacebuilding process through the involvement of youths in peace, security and development. The National Youth Council of Nigeria provides a platform for advancement, mobilization and coordination of youth development and promotion of peace, unity and tolerance across the country.

The term youth is very complex to define and such complexity of the exact meaning of the term youth is a core challenge in conceptualizing its role in peacebuilding and sustainable development. However, a lot of agencies and organizations within the international community have adopted age-based criteria in conceptualizing the term youth, although this classification lacks uniformity. The United Nations and other sister organizations classified youth as someone that fall between the age of 15 to 24 years. Some instances put a lower age below 15 years and an upper age above 24 years. On the other hand, the African Youth Charter, 2006, classified youth as persons between the ages of 15 and 35 years. Similarly, Nigeria's 2009 National Youth Policy chronologically defined youth as persons of age 18 to 35 years.

The Federal Government of Nigeria through the National Youth Policy stipulates that the United Nations projection puts Nigeria as the seventh most populous nation and also the most populous black nation on earth. The UN projection put Nigeria's population as above 206 million people as of 2020. Out of this population, persons between the ages of 15 to 35 represent $23 \%$ which is 47.38 million. The National Youth Policy document also indicates 
that Borno state was ranked $7^{\text {th }}$ in terms of population in Nigeria with a population of above 5 million. The population of persons between 15 to 35 years stood as $21 \%$ that is 1.05 million.

Furthermore, as of 2019, Maiduguri housed 3.4 million people. This huge population was a result of the high influx of internally displaced persons (IDPs) due to the Boko Haram conflict. Persons between 15 to 35 years represented $25 \%$, that is 850,000 .

These demographic realities shift our focus towards understanding the change, positive action, and also of the potentials the young people have which make the subject growing research interest. The recent wave of social uprisings and humanitarian crises in different parts of the country is a piece of evidence in this regard, especially in Maiduguri, Borno state, which is the epicentre of the Boko Haram Conflict.

This is evidenced by the events that took place in 2014 at Maiduguri, the Borno state capital when a group of youths come together to form what is called Kato da Gora which was later officially named the Civilian Joint Task Force (CJTF). The objective of the Kato da Gora otherwise called CJTF was to collaborate and work with security agencies to ensure that Boko Haram is eliminated or pushed out of Maiduguri. The youths collectively put their heads together and pushed Boko Haram out of Maiduguri and its environs, hence the beginning of the peace process.

\section{OBJECTIVE OF STUDY}

The objective of the study is to examine the role youths can play in aiding peacebuilding in Maiduguri, Borno state. This role could be in line with collaborative efforts with governmental organisations, civil society organizations, and non-governmental organization (both local and international) in addressing development indices such as societal inequalities, massive poverty, unemployment etc. which are believed to be among the causes of Boko Haram Conflict in Maiduguri, Borno State so as avoid future occurrences of violent conflicts.

\section{METHODOLOGY}

This is a review paper, which relies mainly on research works such as thesis, dissertations, research journals, newspapers and magazines among others and is to examine how the involvement of youths in peacebuilding process can promote sustainable peace in Maiduguri, Borno State, as a result of the Boko Haram conflict in order to avoid future occurrences of such conflicts. A multidisciplinary research method was employed in is the pursuit of reliable data with the help of numerous specialized branches of learning to achieve common ground aided by the knowledge of other disciplines. Multidisciplinary research is an investigation or inquiry to a problem for ascertaining the hypothesis combining many academic approaches, fields or methods

\section{THE ORETICAL FRAMEWORK}

The study adopts the theory of human development and human needs. The theories explain the developmental indices in a social setting in relation to sustainable peace, security and development. The failure of society to provide basic amenities to the people was considered as the root cause of conflict. 
All humans have basic needs, and failure to achieve these can lead to violent conflict as a way to survival. Therefore, the paper's argument are; developmental indices such as societal inequality, massive poverty, high level of corruption, institutional decay, poor policy programming and economic mismanagement. These are factors that have contributed to the Boko Haram conflicts in the first instance and therefore, the government need to address them in order avoid the insurgency in a near future. The study adopts the sociological theory of human development. The goal of social development in the context of modern welfare is to produce social well-being that makes people capable of acting and making their own decisions in the broadest sense.

The concepts of human needs and conflict are interrelated and affect all aspects of human life. Therefore, human needs theories propose that all humans have certain basic universal needs and that when these needs are not met conflict is likely to occur. Danesh (2011) categorized the theory of universal basic needs into survival and betterment needs. Survival needs require physical and mental well-being, respect from others, and self-esteem (happiness) while betterment needs include a safe, healthy environment, logical reproductive practices, appreciation of life and doing good things (containment).

The proponents of the human needs' theories try to distinguish human needs and interests and, argue that conflicts emerge when people's efforts to meet their universal basic needs are frustrated. Furthermore, they argued that conflict and even violence are inevitable because human needs are non-negotiable, while human interests are open to negotiation and compromise. The antagonist draws a demarcating line between needs and interests and holds the view that the concept of needs and interest are not very clear and itself subject to dispute.

For the antagonists, there are significant questions that remain to be answered. How human needs can be defined? Are human needs universal or cultural? Are human needs hierarchical? How Can human needs and interests be distinguishable? Can conflicts emerging from un achieved need differentiated from those caused by unmet interests? These questions concerning needs, interests, and conflict require a better understanding of the nature of human conflicts and their genesis.

Human conflict and human development go hand in hand. Therefore, human development is a development model that is about creating an environment in which people can develop their full potential and lead productive, creative lives following their needs and interests, thus bringing the focus back onto people (Rakhi, 2011). Human development disperses the concentration of the distribution of goods and services that underprivileged people need and center its ideas on human decisions. By investing in people, we enable growth and empower people thus developing human capabilities. The most basic capabilities for human development are to lead long and healthy lives, to be knowledgeable, to have access to the resources and social services, needed for a decent standard of living and to be able to participate in the life of the community. Without these, many choices are simply not available, and many opportunities in life remain inaccessible. 


\section{FINDINGS}

The knowledge, zeal and energy of young people have been recognized by the United Nations for long and that they are important for the continuing development and peaceful coexistence of the societies in which they live (UN, 2015).

To ensure relevant representations, young people need to be included as stakeholders and future leaders in the peacebuilding process so that the active part of the society is well represented and equipped to positively contribute to the peace and security of the society (Cursi, 2017). Youth can assume a critical job in peacebuilding when engaged by suitable components and methodologies that accommodate their significant support. Peace experts' and policymakers have concurred that there is an essential job that adolescent can play in peacebuilding endeavors (Kemper, 2005; McEvoy-Levy, 2006; Smith and Smith, 2012).

Since 2009, insecurity in the North-East of Nigeria a result of Boko Haram insurgency has led to the loss of over 20,000 lives and the displacement of over two million people. Throughout the region livelihoods have been disrupted, and homes, public buildings (schools, hospitals, markets) and infrastructure including farmlands destroyed, livestock (FGN, 2016). In many areas, land mines and other remnants of war bring challenges for safe and voluntary return (FGN, 2016).

There is a process, led by the Government of Borno in collaboration with the Federal Government of Nigeria, supported by local, national and international partners, helping in identifying the physical, social and economic impacts of the conflict in Borno State in general and Maiduguri in particular, and will inform the process of stabilization, peacebuilding and recovery in the state.

This is evidenced by the events that took place in 2014 at Maiduguri, the Borno state capital when a group of youths come together to form what is called Kato da Gora which was later officially named the Civilian Joint Task Force (CJTF). The objective of the Kato da Gora otherwise called CJTF was to collaborate and work with security agencies to ensure that Boko Haram is eliminated or pursuit out of Maiduguri. The youths collectively put their heads together and pursue Boko Haram out of Maiduguri and its environment, hence the beginning of the peace process.

The paper's findings highlight some of the peacebuilding activities that Maiduguri youths are engaged-in for long-term and sustainable development. These activities are carried out in collaboration with the National Youth Council of Nigeria on one hand and governmental and non-governmental organizations (local and international) including civil society organizations on the other hand. These activities are geared toward the advancement, mobilization and coordination of youths for the promotion of peace, unity and tolerance. Thus;

1. In collaboration with Global Peace Foundation, they organized sensitization campaign on conflict resolution for Maiduguri youths with clubs and associations

2. Organized workshop on voter education for young people in conjunction with Youth Federation for World Peace

3. Produced Peace Flight, a Radio Nigeria programme on peacebuilding in Borno State

4. Organized programme on peacebuilding and conflict resolution, in partnership with American Corner and the University of Maiduguri,

5. sent a delegation of young people to the National Youth Peace Concert from Borno state 
6. Participated in the workshop for young people and community leaders with the theme as: "youth as agent of violence free elections".

Therefore, participatory democracy, youth empowerment, and social wellbeing are critical drivers of sustainable development, peace and security not only in Maiduguri, Borno State, but Nigeria as a whole. Towards achieving the 2030 sustainable development agenda of the United Nations, there is the need for strong and inclusive partnerships between young people and all stakeholders. This will go a long way in addressing the development challenges facing our communities such as unemployment, political exclusion, marginalization, lack of access to education and health, etc. (UN, 2015.

\section{CONCLUSION}

Youth are leaders, not only for tomorrow, but for today. It is, important, therefore to involve youths in any strategy of peacebuilding and sustainable development. Therefore, age, should not be considered as a leadership factor, as such providing appropriate mechanism, strategy, and governance contexts would likely enable young people to flourish as leaders today. In other words, they need to be treated as leaders today without postponing it to an elusive future whether it is in governance in general or peacebuilding and sustainable development programmes specifically.

\section{RECOMMENDATIONS}

Real peace, as it has been widely and universally acknowledged cannot be established until democracy and good governance, human rights and dignity as well as a sound economic system be ensured (Chakwa, 2018). For youths to be strong peacebuilding agents in Maiduguri, Borno State, the paper therefore recommends the following;

- working for democracy and human rights,

- making public opinion regarding the essence of peace and humanity,

- strengthening the fight against discrimination, poverty, gender injustices, malnutrition, and hunger,

- $\quad$ spreading the idea of peace and non-violence way of life,

- creating as well as lead peace movement against racism, and militarism,

- providing voluntary service to the people during human-made and natural disasters,

- creating public awareness about the problems and dangers of weapons of mass destruction, and terrorism etc.,

- making a network of multi-cultural co-operation in economic, social and cultural areas etc.,

- establishing networks among the youth's organizations that are dedicated to peace and prosperity,

- $\quad$ participating in public policymaking; and

- creating within them a strong desire to serve their local as well as a national community and a sense of responsibility towards a greater future. 


\section{REFERENCES}

Abubakar, A., (2016) The Role of the Military in Restoring Peace to Maiduguri, Borno State. National Open University of Nigeria, Lagos.

Abubakar, B., (2017) Origin and Meaning of Maiduguri. Research Gate, https://www.researchgate.net/publication/318215165

Chakwa, A., (2018) Role of the Youth in Peace-Building. Department of Peace and Conflict Studies, University of Dhaka.

Cursi, D. R., (2017) The Role of Youth in Peacebuilding. Centro Studi Difesa Civile (CSDC), Giovani.

Danesh, H.B., (2011). Human Needs Theory, Conflict, and Peace: In Search of an Integrated Model. In D. J. Christie (Ed.), Encyclopedia of Peace Psychology. Hoboken, New Jersey: Wiley-Blackwell.

Danjibo, N. D., (2009) Islamic Fundamentalism and Sectarian Violence: The Maitastine and Boko Haram Crisis in Northern Nigeria. Peace and Conflict Studies Paper Series.

Federal Government of Nigeria (2019) National Youth Policy (2019-2023); Enhancing Youth Development and Participation in the context of Sustainable Development. Federal Ministry of Youth and Sports Development.

Federal Government of Nigeria (FGN) and United Nation Development Programme (UNDP) (2016) NorthEast Nigeria, Recovery and Peacebuilding Assessment, Component Report.

George F. O., (2019) UN Peacebuilding: George Mason University, School of Conflict Analysis and Resolution in Collaboration with Peace Operation Training Institute

Ikusemoran, M. \& Jimme A. M., (2014) A Decade Assessments of Maiduguri Urban Expansion (20022012 Geospatial Approach. Global Journal of Human-Social Science: B Geography, Geo-Sciences, and Environmental Disaster Management, Vol. 14, (Issue 2, Version 1.0)

Kemper, Y., (2005) Youth in War-To-Peace. Approach of International Organisations. Research Centre for Constructive Conflict Management, Berlin.

McEvoy-Levy, S., (2013). "Youth and Peacebuilding". In Mac Ginty, R., (Ed.), (2013). Routledge Handbook of Peacebuilding, New York: Routledge.

Rakhi, N. S., (2011) University of Calicut School of Distance Education, University of Calicut, Thenjipalam, Calicut University P.O., Malappuram, Kerala - 673635

Smith., A. and Smith, E., (2012) Youth, Education and Peacebuilding. United Nations Education, Scientific and Cultural Organisation (UNESCO) Centre, Policy Forum, Paris.

United Nation (2015) Developing National Sustainable Development Strategies in Post-Conflict Countries. UN Department of Economic and Social Affairs Division for Sustainable Development. 